\title{
Hatékony viselkedésmódosító technikák a testmozgás és az egészséges táplálkozás elősegítésére túlsúlyos és elhízott felnőtteknél; szakirodalmi áttekintés és meta-regressziós elemzések
}

\author{
Effective behaviour change techniques for physical activity and healthy \\ eating in overweight and obese adults; systematic review and meta- \\ regression analyses
}

Ismertető: $\quad$ Nagy Barbara $₫$

Országos Gyógyszerészeti és Élelmezés-egészségügyi Intézet

Szerzők: Gro Beate Samdal, Geir Egil Eide, Tom Barth, Geoffrey Williams, Eivind Meland

Megjelenés: International Journal of Behavioral Nutrition and Physical Activity 2017.

DOI: https://doi.org/10.1186/s12966-017-0494-y

Beküldve: 2017.09.12.

doi: $10.24365 /$ ef.v58i3.180

Kulcsszavak: táplálkozásra és a fizikai aktivitásra vonatkozó viselkedési stratégiák összehasonlítása, személyközpontú-, autonómiát támogató kommunikáció

\section{ÖSSZEFOGLALÁS}

A cikkben bemutatott szakirodalmi áttekintés célja, hogy rámutasson a túlsúlyos és elhízott felnőttek fizikai aktivitásának növelésére és egészséges táplálkozásának elősegítésére irányuló beavatkozások eredményeiben mutatkozó heterogenitásra, a viselkedésváltozást célzó és az egyéb beavatkozási módszerek eredményeinek összevetése révén.

A tanulmányban olyan viselkedési és/vagy kognitív viselkedési stratégiákat alkalmazó randomizált, kontrollált beavatkozások kerültek összehasonlításra, ahol a fő kimeneti változót a fizikai aktivitás és/vagy az étkezési szokások alakulása jelentette rövid ( $\leq 6$ hónap) és hosszú távon ( $\geq 12$ hónap). A hatásméretek, a heterogenitási indexek és a regreszsziós együtthatók becsléséhez meta-analízist és meta-regressziót alkalmaztak a szakértők.

Az eredmények azt mutatták, hogy a táplálkozásra és a fizikai aktivitásra vonatkozó viselkedés változást célzó beavatkozások rövid és hosszú távon is csak mérsékelten hatékonyak, heterogenitásuk pedig magas, különösen rövidtávon. A tanulmány rámutat, hogy a személyközpontú és az autonómiát támogató kommunikációs stílust hangsúlyozó beavatkozások, mint pl. a motivációs interjú vagy az öndeterminációs-elmélet azok, amelyek hosszú távon hatásosak lehetnek.

\section{KULCSÜZENET A SZAKEMBEREK SZÁMÁRA}

Az eredmények alátámasztják a célbeállitást és a magatartás önellenőrzésének alkalmazását a túlsúlyos és elhízott felnőttek tanácsadásánál. A személyközpontú és autonómiát támogató tanácsadói megközelítés használata kulcsfontosságú a kívánt viselkedés időbeli fenntartása érdekében. 